\title{
Charles C. Mann, 1493. Świat po Kolumbie, Dom Wydawniczy REBIS, Poznań 2012, ss. 712
}

Problematyka wielorakich przemian świata i człowieka, która wpisana jest w rozwój cywilizacyjny ludzkości jest jednym z elementów szeroko pojętej kultury. Dynamika ta jest niezwykle twórcza, choć może nieść w sobie także znamiona zła czy niedoskonałości. Można stosunkowo łatwo wskazać na pewne szczególnie znaczące wydarzenia, miejsca czy osoby, które stały sie szczególnie symbolicznymi rzeczywistościami, chyba już na zawsze wpisanymi w historię. Nie ulega wątpliwości, że jednym z takich fenomenów była wyprawa Krzysztofa Kolumba w 1492 roku i odkrycie Nowego Świata.

Autor omawianej książki wydał także wcześniej opracowanie pt. 1491. Ameryka przed Kolumbem (Poznań 2008). Jest ono ciekawą refleksją, tak ze względu na treść, jak i na formę oraz wielość podjętych wątków. Stało się wręcz pewnym symbolem refleksji wokół tej tematyki, co więcej poszerzyło znacznie krąg zainteresowanych. Obecnie zaś Charles C. Mann zainteresował się czasem po roku 1492, ale już nie tylko w Ameryce lecz obejmując niemal cały świat, i to na dużej przestrzeni czasu. Już tutaj jawi się pytanie, czy mu się to udało, a jeśli tak, to w jakim stopniu?

Książkę otwiera dedykacja (s. 5), mapa świata 1493 (s. 6-7) oraz Prolog (s. 9-18). Dalej zamieszczono wprowadzenie, które opatrzone zostało tytułem: Czas homogenocenu (s. 19-64). Faktycznie składa się na nie jeden blok o temacie: Dwa pomniki (s. 21-64). Zasadniczy korpus książki podzielony jest na cztery części. Jednocześnie poszczególne bloki w ich ramach mają ciągłą numerację. A oto schematyczny obraz zawartości treściowej książki Charlesa C. Manna rozpisany generalnie w postaci spisu treści, który jest raczej ideowymi hasłami - zwłaszcza tytuły poszczególnych rozdziałów. Trudno bowiem tutaj podejmować 
Sprawozdania i recenzje

się szerszego opisu treści, który i tak nie odda wielowątkowości i bogactwa książki:

Część pierwsza: Podróże przez Atlantyk (s. 65-171) składa się z dwóch bloków: Wybrzeże tytoniowe (s. 67-114) Złe powietrze (s. 115-169).

Część druga: Podróże przez Pacyfik (s. 173-265) ma także dwa bloki: Statki petne pieniędzy (Jedwab za srebro, odstona pierwsza) (s. 175-227) Trawa nieszczęśliwej mitości, zamorskie bulwy i jadeitowy ryż (Jedwab za srebro, odstona druga) (s. 228-265).

Część trzecia: Europa w świecie (s. 267-376) podzielona została na: Kompleks rolniczo-przemystowy (s. 269-323) Czarne złoto (s. 324-376).

Część czwarta: Afryka w świecie (s. 377-509) zawiera także dwa rozdziały: Zwariowana zupa (s. 379-440) Las uciekinierów (s. 441-509).

Koda to tematy: Nurty życia (s. 511-531) W Bulalacao (s. 513-531).

Następnie zamieszczono dwa aneksy: Walczące światy (s. 532-537) oraz Globalizacja w wersji beta (s. 538-542). Dodano jeszcze dość obszerne podziękowania (s. 543-547).

Znaczną część książki stanowią różne interesujące elementy formalne. W kolejności zamieszczono: przypisy (s. 549-627), bibliografia (s. 628-699), indeks geograficzny (s. 700-701), indeks osób (s. 702-704), mapy - prawa autorskie (s. 705-706), ilustracje - prawa autorskie (s. 707-708), diagramy, prawa autorskie (s. 709), spis map (s. 710) i spis treści (s. 711-712).

Jednym ze swoistych ukierunkowań lektury prezentowanej książki mogą być słowa $\mathrm{z}$ wprowadzenia:

Dziś ekologiczne i gospodarcze wstrząsy wydają się promieniowaniem tła na naszej coraz bardziej zatłoczonej i niestabilnej planecie. Może się nam wydawać, że spotkanie japońskiego drwala w Brazylii, chińskiego inżyniera w Sahelu, Europejczyków wędrujących z plecakami po Nepalu bądź zajmujących najlepsze stoliki w nowojorskich klubach i barach to coś charakterystycznego wyłącznie dla naszych kosmopolitycznych czasów - ale to wszystko na różne sposoby i pod różnymi postaciami trwa już od stuleci. Wydarzenia sprzed pół milenium mogą nam co najwyżej przypomnieć, że nie tylko naszemu pokoleniu przyszło żyć $\mathrm{w}$ takiej pogmatwanej rzeczywistości. Warto więc się przyjrzeć, jak do tego doszło (s. 64).

To jednak nie zwalnia z obowiązku szukania nowości organizacyjnej świata, i to we wszystkich dziedzinach życia.

Wejście w bogactwo wielorakich przemian w świecie po 1492 roku wskazuje, że jawią się one wręcz jako imponujące, czasem o niezwykłych konsekwencjach, choć nie zawsze ściśle zaplanowane i przewidywane. Wiele wzajemnie przenikających się procesów cywilizacyjnych 
i zjawisk społecznych dotyczy niemal wszystkich dziedzin ludzkiego życia, i to w wielu konkretnych zakątkach świata. Co więcej, zdają się one przybierać charakter ponadnarodowy, a nawet globalny. Czasem może nawet wymykają się ze ścisłej kontroli, a może niekiedy właśnie o to chodzi.

W prezentowanej książce autor udowadnia, że wymiana światowa po 1492 roku legła u podstaw wielu wątków późniejszej historii ludzkości. Analizując najnowsze badania antropologów, archeologów, ekologów i historyków, stara się ukazać, jak powstanie tej globalnej wymiany biologicznej i gospodarczej stymulowało rozwój Europy i przyczyniło się do przemian także na innych kontynentach. Charles C. Mann zdaje się dowodzić, że skutki tych przemian odczuwa także dzisiejszy świat w postaci skomplikowanych problemów współczesności: od masowego przemieszczania się ludności poprzez politykę handlową, aż po wojny kulturowe.

Z innej strony lektura książki potwierdza słuszność stwierdzenia autora z Prologu:

Ta książka nie jest i nie miała być systematycznym przedstawieniem ekonomicznych i ekologicznych korzeni tego, co niektórzy historycy pompatycznie, lecz nie bez racji, nazywają porządkiem świata. Niektóre zakątki Ziemi świadomie pominąłem; o pewnych ważnych wydarzeniach ledwie napomknąłem. Na usprawiedliwienie mogę tylko powiedzieć, że temat jest zbyt obszerny jak na jedno opracowanie. Nawet zarys takiego całościowego ujęcia byłby nieporadny i nie do strawienia dla czytelnika. Nie prześledziłem też od początku do końca dróg, jakimi naukowcy dochodzili do konkluzji tu zaprezentowanych, choć nie omieszkałem wskazać kamieni milowych (s. 14).

Jednak pełny tytuł książki rodzi o wiele większe nadzieje i oczekiwania. Sugeruje niezwykle kompleksowe i szerokie dzieło. Faktycznie, obecne jest do pewnego stopnia, monumentalne w swej objętości, ale na pewno nie treści. Autor chyba przesadził w swych zamiarach i niestety nie sprostał tak zakreślonemu szerokiemu obrazowi. Być może, gdyby ograniczył się zdecydowanie do treści, które można byłoby określić „Ameryka po Kolumbie”, wówczas książka zdecydowanie zyskałaby na swej kompetencji i bardziej pogłębionych analizach.

Autor jeszcze raz, w jakimś sensie, sam się usprawiedliwia ze swoich spodziewanych zastrzeżeń pisząc: „«Rok 1493» koncentruje się na obszarach, które wydają się mi szczególnie istotne, najlepiej udokumentowane lub - i tu widać moje dziennikarskie skrzywienie - po prostu najciekawsze. Czytelnika żądnego głębszej wiedzy zachęcam natomiast do skorzystania ze źródeł wymienionych w bibliografii" 
Sprawozdania i recenzje

(s. 14). Jest to unik, czy może świadome stwierdzenie własnych braków i niedociągnięć. Dobrze, że sam w końcu wprost stwierdza: „Niemniej za wszystko, co w «1493» umieściłem, odpowiadam sam, z problemami włącznie" (s. 543).

Wydaje się, że pasjonująca lektura książki 1491. Ameryka przed Kolumbem rodzi jakby podobne oczekiwania także wobec obecnie prezentowanej pracy Charlesa C. Manna. Tamto dzieło interesująco otwierało czytelnika ku lekturze, wręcz wciągało. Wydaje się nawet, że w znacznym stopniu zaspokajało te oczekiwania. Dlatego czytelnik, może nawet jakoś zmanipulowany, pragnie podobnych doświadczeń, tak naukowych, jak i często wręcz emocjonalnych, sięgając po tę pracę. Niestety, niemal od początku odczuwa się tutaj brak owego ducha, owego czytelnego i zarazem tak dynamicznego obrazu świata po Kolumbie, jak to ukazywała wcześniejsza praca. Jakże to inne kreślenie dynamiki obrazu przemian ludzkich! Niestety, zapewne autor uwierzył w automatyczny sukces, nie przykładając już tak dużej staranności.

Dobrze, że autor wprost zauważa: „Poszczególne rozdziały «1493» wiele zawdzięczają pojedynczym publikacjom" (s. 544), a dziś jest ich już wiele. Wydaje się, że jest to jednocześnie jasna gwarancja merytoryczności proponowanych treści, a z drugiej strony wskazanie na szczególnie ważne pomoce bibliograficzne. Słusznym jest umiejętne czerpanie od innych, zwłaszcza, gdy prezentują dojrzałe badania i przemyślenia.

Ze wszech miar słuszna jest uwaga autora odnosząca się do sfery językowej: „Książki takie jak to nieuchronnie wiodą autora na terminologiczne pole minowe. Problemy, z jakimi przychodzi mu się borykać, są trojakie. Po pierwsze, liczne słowa w powszechnym użyciu bywają mylące co do znaczenia, a niektóre mogą być nawet w pewnych sytuacjach odbierane jako ubliżające. Po drugie, ludzka percepcja jest bardzo zróżnicowana i określenie z jednego punktu widzenia precyzyjne może się wydawać zupełnie nieadekwatne $\mathrm{z}$ innego. Po trzecie wreszcie, niektóre słowa w przeszłości były rozumiane inaczej niż obecnie - i może się zdarzyć, że autor w dążeniu do dokładności historycznej posłuży się tym dawnym znaczeniem, zgodnym z kontekstem miejsca i epoki, a nieświadomy tego zabiegu odbiorca odczyta to w zupełnie inny sposób" (s. 532). Warto naturalnie o tych zastrzeżeniach pamiętać. Oczywiście, możliwe jest tutaj wskazanie jeszcze na inne niebezpieczeństwa.

Cennym uzupełnieniem tak szerokiej treściowo książki są zamieszczone reprodukcje, i to ze stosunkowo obszernymi opisami. Ich bogactwo daje dodatkowe wizualne doświadczenie proponowanych 
treści, a więc wydarzeń oraz osób. Niezwykle ważną pomocą są także liczne mapki. Ułatwiają one geograficzne śledzenie wielu wydarzeń historycznych i ich rozeznanie w geografii światowej; pozwalają dość łatwo geograficznie umiejscowić i rozeznać niekiedy dużą kompleksowość szczegółowych wydarzeń historycznych oraz personalnych, które opisywane są przez Charlesa C. Manna.

Wręcz monumentalne jest zestawienie bibliografii prezentowanego opracowania. Zresztą sam autor sugeruje sięganie do niego już w osobistym, bardziej pogłębionym studium, które może przybrać różne kierunki zainteresowań (s. 14). Warto dodać, że zaznaczono także pozycje, do których od 2011 roku jest darmowy dostęp w internecie, co jest ważnym wskazaniem zwłaszcza dla prac w językach obcych, dzięki temu bardziej dostępnych (s. 699). Dobrze, że wskazano także na polskie przekłady niektórych ważniejszych, wręcz dziś już symbolicznych i fundamentalnych dzieł, np. H. Cortesa, B. de Las Casas czy M. Webera. Nie ma jednak w tym względzie konsekwencji.

Z uznaniem należy wskazać na przypisy bibliograficzne. Niektóre z nich zawierają także interesujące komentarze, wyjaśnienia czy dopowiedzenia. To jest istotny element prowadzonej narracji. Ważnym uzupełnieniem, zazwyczaj informacyjnym, są także przypisy od tłumacza czy redakcji (np. s. 228, 302, 313, 360, 382, 433, 536). Świadczy to o powadze tłumacza oraz edytora. Lektura polskiego czytelnika będzie w oparciu o te informacje znacznie ułatwiona, a jednocześnie bardziej odpowiedzialna.

Jak zawsze, znaczącą pomocą w lekturze książki, zwłaszcza historycznej, są odpowiednie indeksy. Gdy idzie jednak o indeks osób, jawią się liczne wątpliwości. Brak bowiem w wykazie wielu postaci występujących wcześniej w tekście (np. s. 416-417). Do rangi braku dokładności można zaliczyć szczególnie dwa fakty. W pierwszym przypadku dwie różne postacie zostają wskazane przy tej samej osobie. Dwaj synowie H. Cortesa, o tym samym imieniu nie zostali wyróżnieni, oddzielnym wskazaniem (s. 416, 702). Podobnie Izabela I (La Catolica) obejmuje $\mathrm{w}$ indeksie także Tecuichpotzin, potocznie zwaną Izabelą (s. 414, 703). Ta ostatnia ma także własne wskazanie w indeksie osób. Dobra redakcja i ewentualna korekta z pewnością rozwiązałyby te problemy. Szkoda, że w pracach historycznych tego typu występują jeszcze takie szkolne błędy i nieścisłości.

Prezentowane opracowanie Charlesa C. Manna doczekało się wyjątkowo szybkiej edycji w języku polskim (2011-2012). Chyba polskie tłumaczenie angielskiego tytułu jest zbyt schematyczne i w znacznym stopniu wypacza dynamikę oryginału angielskiego. Być może tłumacz 
i redakcja oraz konsultacje merytoryczne chciały nawiązać symbolicznie do tytułu poprzedniego dzieła, które zrobiło wielką karierę, a zatem także i określone profity materialne. Być może miało to także stworzyć wrażenie pewnej kontynuacji: Ameryka przed Kolumbem i Świat po Kolumbie.

Bp Andrzej F. Dziuba 